\title{
Comparison of microbiological parameters in experimental and conventional recirculation aquaculturesystems
}

\author{
Ivaylo Sirakov, Katya Velichkova*, Stefka Stoyanova \\ Department of Biology and aquaculture, Faculty of Agriculture, Trakia University, Students campus, 6000 Stara Zagora, Bulgaria.
}

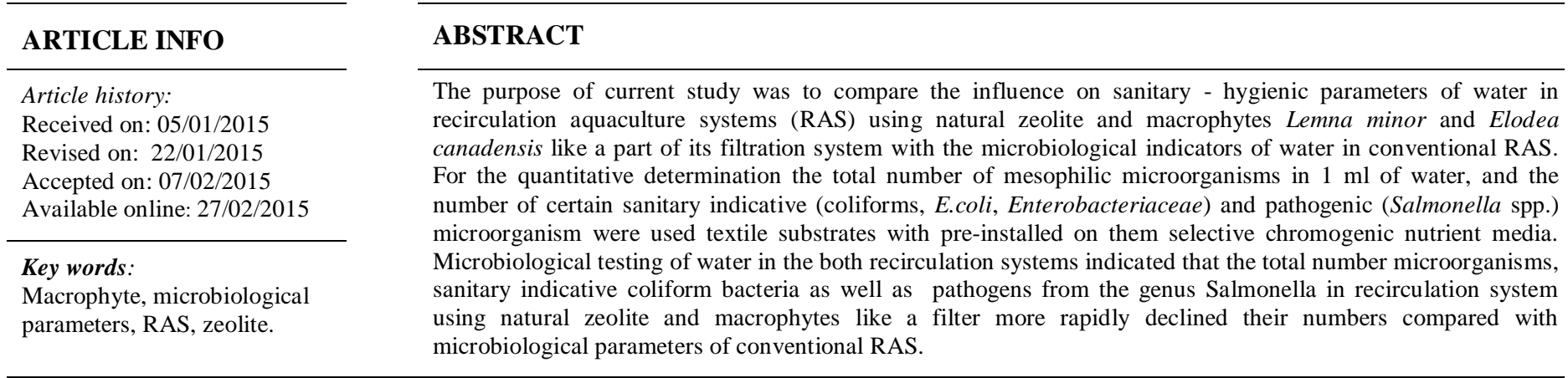

\section{INTRODUCTION}

Recirculation aquaculture systems (RAS) produce aquaculture products on land with minimal water loss and minimal discharge of waste products. RAS minimize water discharge due to mechanical and biological treatment allowing water to be constantly purified [1]. The presence of toxic nitrogenous compounds can be assimilated by higher plants and zeolites [2]. The macrophytes uptake nutrients directly, provide good conditions for physical filtration and reduce water flow [3]. The macrophytes in pond systems performed very well in the removal of coliforms and enterobacteria [4]. Furthermore the zeolite is extremely effective at killing a large number of cells of sanitary bacteria in water over a short amount of time [5]. The water of a RAS includes the presence of large populations consisting of bacteria. In a RAS maintaining the fish health is directly dependent on good water parameters and on the effective control of the microbial populations [6]. A few species (Salmonella sp., Vibrio sp., Aeromonas sp., Flavobacterium sp.) are pathogens and causing diseases in fish, particularly under conditions of stress and immune deficiency. Healthy fish can have potentially pathogenic bacteria for the human on the surface of the skin or within the intestine (and possibly other organs) without showing signs of disease. On the other hand, microorganisms could be transmitted to muscles from gills, skins

* Corresponding Author

K. Velichkova, Department of Biology and aquaculture, Faculty of Agriculture, Trakia University, Students campus, 6000 Stara Zagora, Bulgaria, Phone: +359887646876, E-mail: genova@abv.bg and intestines [7]. Bacterial flora in fishes consists of mainly aerobic or facultative anaerobic [8]. Bacterial analysis of water in aquaculture is not common [9]. Nevertheless water is a living environment for raised fish and if water is contaminated with bacteria this pollution could be transmitted on cultured hydrobionts. By our understanding the studies dealing with the impact of zeolites and macrophytic plants on microbiological parameters in water of RAS are highly limited. The purpose of current study was to compare the influence on sanitary - hygienic parameters of water in RAS using natural zeolite and macrophytes Lemna minor and Elodea canadensis like a part of its filtration system with the microbiological indicators of water in conventional RAS.

\section{MATERIALS AND METHODS}

\subsection{RAS}

The experiment was conducted in two models of recirculation systems. Each of them consisted of 4 tanks (Fig. 1) with volume of $0.06 \mathrm{~m}^{3}$. The first recirculation system (experimental) waste water was treated by a mechanical filter (sedimentation tank), moving bed biofilm reactor where natural zeolites and macrophytic plants from genus Lemna and Elodea were also situated. Zeolites were delivered from deposit "Beliplast", Kyrdjali district, Bulgaria from the company "Bentonit" AD. The zeolite was recharged with a solution of $\mathrm{NaCl}$ $(10 \%)$ every 5 days and replaced fully in the middle of the experiment. Macrophytes were harvested and transported from Zagorka Lake in Stara Zagora, Bulgaria. The macrophytes were determined by Flora Reipublicae Popularis Bulgaricae [10]. 


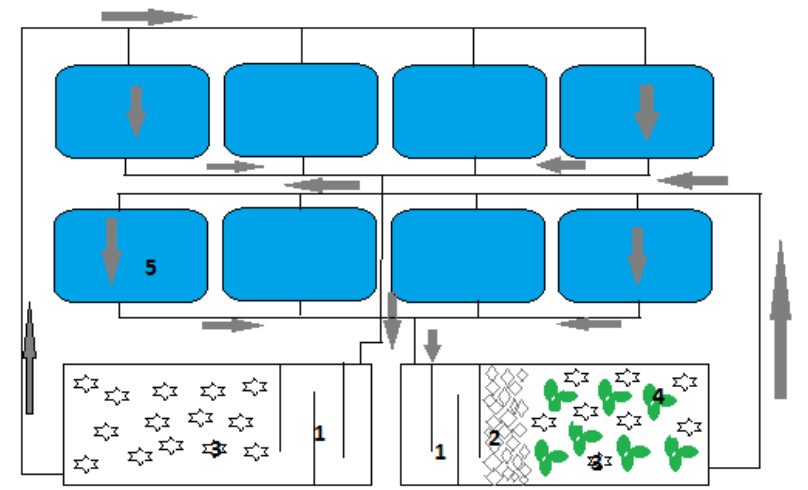

Fig. 1: Control and experimental systems, used during the trial: 1- mechanical filter; 2- zeolites; 3- biological filter; 4- macrophytes Lemna minor and Elodea canadensis; 5- tanks.

The conventional RAS (control) consisted from mechanical filter (sedimentation tank) and biological filter (moving bed biofilm reactor) (Fig.1). Daily fresh water in volume of 201 was added to every system for compensation of water loses from evaporation and for decreasing the quantity of nitrate in water, because denitrification block did not present in the systems. The trial was conducted at Experimental base of aquaculture in Agricultural faculty - Trakia University, Stara Zagora, Bulgaria. The study lasted 40 days. From fish farm Bukovetz were chosen and transported healthy rainbow trout. The stocking density, used during the trial was 200 pcs. $\mathrm{m}^{-3}$. The period of acclimatization of the fish lasted one week.

\subsection{Microbiological indicators}

For the quantitative determination the total number of mesophilic microorganisms in $1 \mathrm{ml}$ of water, and the number of certain sanitary indicative (coliforms, E.coli, Enterobacteriaceae) and pathogenic (Salmonella spp.) microorganism were used textile substrates with pre-installed on them selective chromogenic nutrient media (Rida ${ }^{\circledR}$ Count Total; Rida ${ }^{\circledR}$ Count E.coli/Coliform; Rida ${ }^{\circledR}$ Count Salmonella /Enterobacteriaceae, R-Biopharm AG, Germany). For the purpose of the examined water were prepared serial decimal dilutions of $10^{-6}$. By $1 \mathrm{ml}$ dilutions from $10^{-3}$ to $10^{-6}$ were transferred onto the respective nutrient medium. The cultivation of inoculated samples was carried out in a thermostat at $37^{0} \mathrm{C}$ for $24-48$ hour. Follows counting the grown on the middle colonies and was recorded the fact that specific microorganisms form a different color colonies. The obtained results were expressed as CFU / ml (Colon Forming Units). The received from the trial data were statistically analyzed by T-test (Microsoft office, 2010).

\section{RESULTS AND DISCUSSION}

E. coli is the most resistant of all coliforms and pathogens. Fish contaminated with $E$. coli should be treated with antibiotics and purged in clean water [11]. In this study the quantity of E. coli / Coliform was in the range from $1.65 \times 10^{3}$ to $18.20 \times 10^{3}$ (Fig. 2). As regards the presence of coliforms in the water on both the experimental and control RAS was observed variation in the values and is not reported a significant influence on the experimental set. At the end of the experiment, there was a slight decrease in the number of coliforms in the experimental variant with $10 \%$ compared to control, which is not statistically proven. The attachment of $E$. coli to the macrophytes was rapid and may contribute to the rapid decline of $E$. coli in the water samples [12].

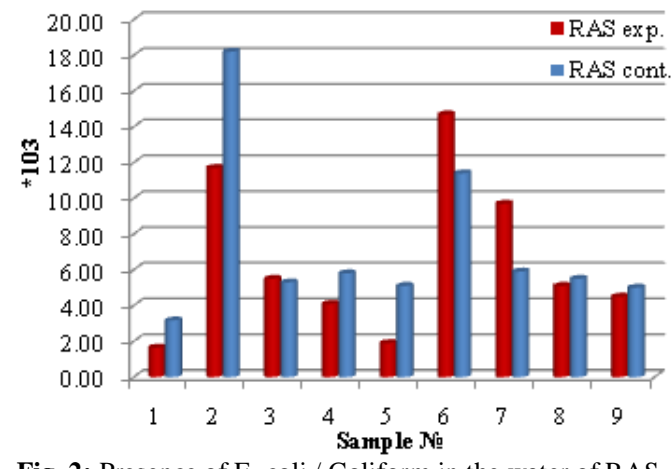

Fig. 2: Presence of E. coli / Coliform in the water of RAS.

In the beginning of the trial the number of aerobic microorganisms in the water of control system was with $97 \%$ higher compared to experimental. The number of aerobic microorganisms in the water of both systems remained relatively constant, and at the end of the experiment significantly reduced (Fig. 3). Aerobic bacteria require oxygen for life support. Aerobic bacteria were present on root surface, suggesting root oxygen release [13]. The zeolite very effectively removes a large number of cells of sanitary bacteria in water over a short amount of time [5,14].

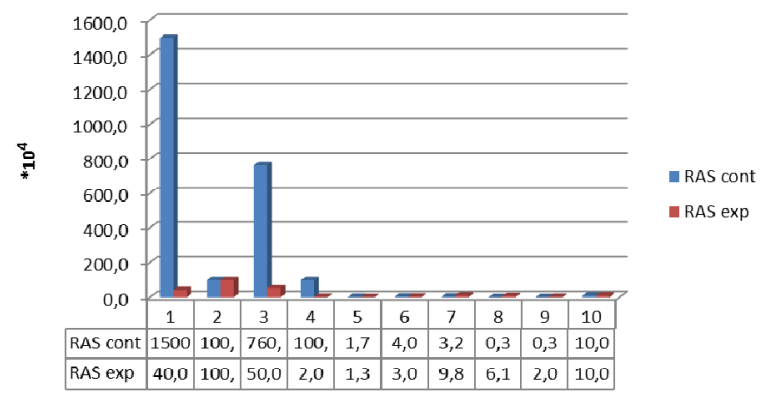

Fig. 3: Presence of aerobic bacteria in the water of RAS.

Salmonella spp. is a pathogenic, nod shaped, gram negative pathogenic bacteria of water bodies in warm climate zones which pose a great risk on human health [15]. In this study the average number of this microorganism is $2.73 \times 10^{2}$ in system with macrophytes and zeolites. Initially was observed a decrease in the number of representatives of the genus Salmonella in both RAS (Fig. 4). In the middle of the period was noted increase of their numbers, and then in the second half of the experiment in the system with macrophytes and zeolites like filter elements the amount of bacteria from genus Salmonella was reduced faster than those in the conventional system. Considering the average number of salmonella bacteria in the experimental system was with $15 \%$ lower compared to the control variant (Table 1). The fecal bacteria could be removed from water attaching to floating aquatic 
macrophytes [16]. Awuah et al. [17] studied duckweed and algal pond system and established that macrophytes pond systems performed better in the removal of coliforms.

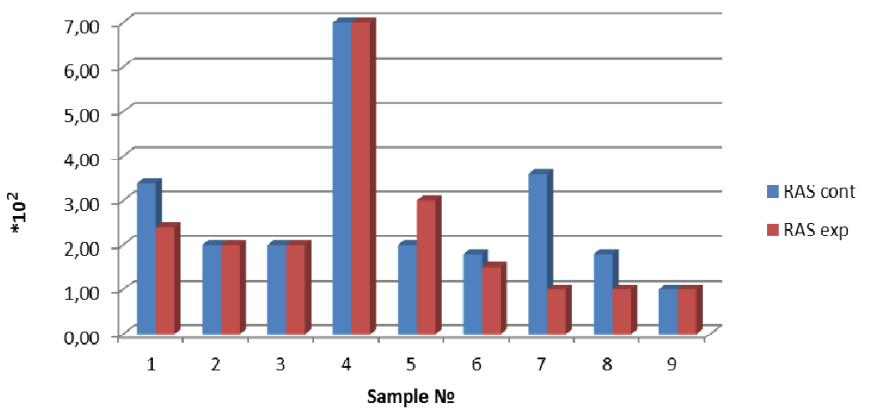

Fig. 4: Presence of bacteria from genus Salmonella in the water of RAS.

The numbers of Enterobacteriaceae colony forming units per milliliter of water average varied from $5.13 \times 10^{3}$ to $6.27 \times 10^{3}$ respectively in the control and experimental system (Table 1). The quantity of the representatives of the family Enterobacteriaceae at the end of the period remains significant (Fig. 5). This applies to a greater degree for a biological filter system, which may be due to the good survival of Enterobacteriaceae in the aquatic environment which finds good conditions for development attachments to the leaf surface and root of macrophytes [18].

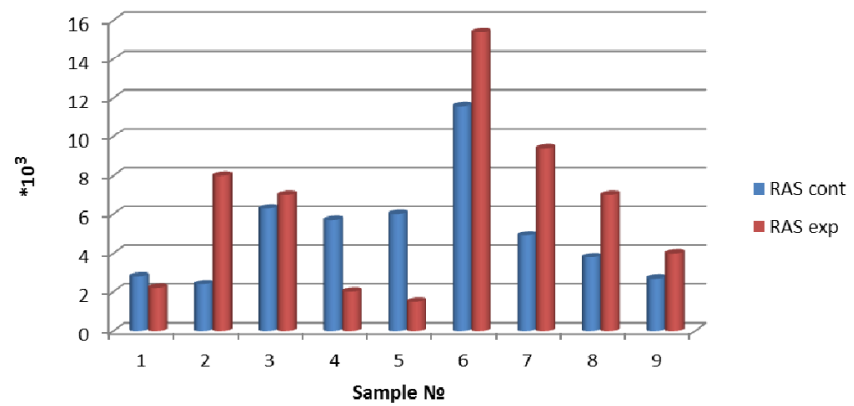

Fig. 5:Presence of bacteria from genus Enterobacteriaceae in the water of RAS.

Table 1: Microbiological indicators of water in RAS.

\begin{tabular}{cccc}
\hline & RAS exp & RAS cont & p \\
\hline & $\mathrm{X} \pm \mathrm{Sx}$ & $\mathrm{X} \pm \mathrm{Sx}$ & \\
Enterobacteria & $6.27 \times 10^{3} \pm 4.47$ & $5.13 \times 10^{3} \pm 2.84$ & $\mathrm{~ns}$ \\
Salmonella & $2.23 \times 10^{2} \pm 1.79$ & $2.73 \times 10^{2} \pm 1.88$ & $\mathrm{~ns}$ \\
E.coli/Coliform & $6.53 \times 10^{3} \pm 4.49$ & $7.26 \times 10^{3} \pm 4.66$ & $\mathrm{~ns}$ \\
Aerobic bacteria & $22.42 \times 10^{4} \pm 32.1$ & $247.94 \times 10^{4} \pm 498.1$ & $\mathrm{~ns}$ \\
\hline $\mathrm{P} \leq 0.05^{*}, \mathrm{P}<0.01^{* *} \mathrm{P}<0.001 * * * \mathrm{P} \geq 0.05-\mathrm{ns}$ & &
\end{tabular}

\section{CONCLUSION}

Microbiological testing of water in the both recirculation systems indicated that the total number microorganisms, sanitary indicative coliform bacteria as well as pathogens from the genus Salmonella in recirculation system using natural zeolite and macrophytes like a filter more rapidly declined their numbers compared to microbiological parameters of conventional RAS. The influence of zeolite and macrophytes on bacteria from family Enterobacteriaceae wasn't significant.

\section{REFERENCES}

1. Martins C, Eding E, Verdegem M, Heinsbroek L, Schneider O, Blancheton J, Roque d'Orbcastel E, Verreth J. New developments in recirculating aquaculture systems in Europe: A perspective on environmental sustainability. Aquacultural Engineering. 2010; 43(3): 83-93.

2. Booker N, Cooney E, Priestley A. Ammonia Removal from Sewage using Australian Zeolite. Wat. Sci. Tech. 1996; 34(9): 17-24.

3. Brix H. Functions of macrophytes in constructed wetlands. Water Sci. Tech. 1994; 4: 71-78.

4. Awuah E. Pathogen Removal Mechanisms in Macrophyte and Algal Waste Stabilization Ponds. Dissertacion, Published by: Taylor \& Francis/Balkema; 2006

5. McDonnell A, Beving D, Wang A, Chen W, Yan Y. Hydrophilic and antimicrobial zeolite coatings for gravity-independent water separation. Adv. Funct. Mater. 2005; 15 (2): 336-340.

6. Michaud L, Lo Giudice A, Troussellier M, Smedile F, Bruni V, Blancheton J. Phylogenetic characterization of the heterotrophic bacterial communities inhabiting a marine recirculating aquaculture system. Journal of Applied Microbiology. 2009; 107: 1935-1946.

7. Patir B, Inanli A. Microbiological quality and TMA-N levels of fresh horse Mackerel (Trachurus mediterraneus, S. 1868) marketed in elazig. F.U. Fen ve Muhendislik Bilimleri Dergisi. 2005; 17: 360369.

8. Cahill M. Bacterial flora of fishes: A review. Microbial Ecology. 1990; 19 (1): 21-41.

9. Brown E, Gratzek J. 1980. Fish Farming Handbook. Van Nostrand Reinhold, New York; 1980.

10. Jordanov D, Kitanov B, Valev S. 1963. Flora Reipublicae Popularis Bulgaricae, Sofia, Acad. Press; 1963 (Bg).

11. Pal D, Gupta C. 1992. Microbial Pollution in Water and its Effects on Fish. Journal of Aquatic Animal Health. 1992; 4: 32 - 39.

12. Kleinheinz G, Coenan A, Zehms T, Preedit J, Leewis M, Becker D, McDermott C. Effect of aquatic macrophytes on the survival of Escherichia coli in a laboratory microcosm. Lake and Reservoir Management. 2009; 25 (2): 149-154.

13. Gagnon V, Chazarenc F, Comeau Y, Brisson J. Influence of macrophyte species on microbial density and activity in constructed wetlands. Water Sci Technol. 2007; 56 (3): 249-54.

14. Barth-Wirsching U, Höller H. 1989. Experimental studies on zeolite formation conditions. Eur J Mineral. 1989; 1: 489-506.

15. Heinitz M, Ruble R, Wagner D, Tatini S. Incidence of Salmonella in fish and seafood. J. Food Prot. 2000; 63: 579-592.

16. Spira WM, Hug A, Ahmed QS, Saeed YA (1981). Uptake of Vibrio cholerae biotype eltor from contaminated water by water hyacinth (Eichhornia crassipes). Appl. Environ. Microbiol. 1981; 42: 50-553.

17. Awuah E, Oppong-Peprah M, Lubberding HJ, Gijzen HJ Comparative performance studies of macrophyte and algal-based stabilization ponds. J. Toxicol. and Environ. Health. 2004; 67: 1-13.

18. Awuah E, Anohene F, Asante K, Lubberding HJ and Gijzen HJ. Environmental conditions and pathogen removal in macrophyte and algal-based domestic wastewater treatment systems. Wat. Sci. Tech. 2001; 44 (6): 11-18

\section{How to cite this article:}

Ivaylo Sirakov, Katya Velichkova, Stefka Stoyanova. Comparison of microbiological parameters in experimental and conventional recirculation aquaculture systems. J App Biol Biotech, 2015; 3 (01): 021-023. 